\title{
PENERAPAN MANAJEMEN RISIKO KREDIT PADA PEMBIAYAAN SYARIAH DI KOPERASI AS SAKINAH SIDOARJO
}

\author{
Nur Laila \\ Zainuddin Maliki \\ e-mail: romila15@yahoo.com/ telp. +62 8165405792
}

\begin{abstract}
Credit risk is one of the most frequent risks in tough financing such as on financing using ijarah and murabahah contracts in Sharia financial institutions. The reason is due to mistakes in the analysis of financing applications and lack of cooperative readiness in managing and anticipating the possibility of risk exposure in the institution. In other hand, sharia cooperatives follow the principle of lost and profit sharing that requires a careful cooperative in managing their business in order to achieve the expected profit target.

As Sakinah Cooperation Sidoarjo which has been operating for 19 years only experienced credit risk less than 1\%. Therefore, this study is aimed to firstly understand and describe to what extent the implementation of risk management in sharia financing in As Sakinah Cooperation Sidoarjo is, and secondly, to understand and describe the credit risk settlement scheme that occurs in sharia financing in As Sakinah Cooperation Sidoarjo.

This research used qualitative method, using a case study approach. Data are collected through interview technique at main source and documents and regulation of the cooperation as secondary data source. The data were analyzed through 3 (three) steps. They are data deduction, data display and conclusion and verification.

The results show that the role of the group and the joint responsibility system become the key in reducing credit risk
\end{abstract}

Keywords: management, risk, credit, Ijarah, Murabahah.

\section{PENDAHULUAN}

Dalam sepuluh tahun terakhir laju pertumbuhan lembaga keuangan syariah di Indonesia cukup signifikan. ${ }^{1}$ Banyak lembaga keuangan termasuk koperasi yang awalnya beroperasi secara konvensional beralih menjadi syariah, sehingga masih

\footnotetext{
${ }^{1}$ Nofinawati, Perkembangan Perbankan Syariah Di Indonesia,JURIS Volume 14, Nomor 2 (Juli-Desember 2015), 176
} 
banyak kebijakan yang belum sepenuhnya sesuai dengan ketentuan yang berlaku.

Perbedaan prinsip antara pola konvensional dan pola syariah menuntut koperasi syariah untuk berhati-hati dalam melakukan kegiatannya karena sistem syariah berprinsip loss and profit sharing yang memerlukan penghitungan yang cukup rumit. Paling tidak ada tiga masalah yang dihadapi koperasi ketika menyalurkan pembiayaan, yakni masalah ketidakpastian kondisi pasar yang akan mempengaruhi kemampuan nasabah dalam mengembalikan dana, adanya kemungkinan perbedaan nilai jual agunan pada waktu kontrak dan ketika terminasi, dan tentang kredibilitas informasi nasabah yang berpengaruh pada limit, tenor, margin, serta nilai dan bentuk pinjaman yang diminta. $^{2}$

Kendala yang seringkali membuat koperasi memiliki risiko yang tinggi adalah tidak adanya pengawasan aktif, kecukupan kebijakan dan prosedur manajemen risiko serta penetapan limit risiko, dan kecukupan proses identifikasi, pengukuran, pemantauan, dan pengendalian risiko serta sistem informasi manajemen risiko, dan sistem pengendalian intern yang menyeluruh. $^{3} \quad$ Rendahnya kualitas

\footnotetext{
${ }^{2}$ Imam Wahyudi, Miranti Kartika Dewi, Muhammad Budi Prasetyo, Niken Iwani Surya Putri, Banu Muhammad Haidir, Manajemen Risiko Bank Islam, (Jakarta: Salemba Empat, 2013), 91

${ }^{3}$ Peraturan OJK Nomor 65/POJK.03/2017 tentang Penerapan Manajemen Risiko Bagi Bank Umum Syariah Dan Unit Usaha Syariah
}

SDM pengelola juga menjadi eksposur risiko tersendiri. Meski demikian, tidak semua koperasi mempunyai kebijakan mengantisipasi risiko dengan manajemen yang baik, sehingga tidak ada pedoman yang baku dan kekuatan hukum yang cukup dalam setiap penyelesaian masalah yang terjadi. Hal ini rawan akan munculnya risiko lanjutan seperti risiko likuiditas, risiko operasional, risiko reputasi, risiko strategik, risiko kepatuhan, dan risiko imbal hasil.

Beberapa penelitain yang pernah dilakukan terkait manajemen risiko kebanyakan dilakukan di lembaga keuangan Bank, yakni di BTN Syariah ${ }^{4}$ dan Bank Sulutgo ${ }^{5}$. Sementara dari sisi akad ditekankan pada akad murabahah. ${ }^{6}$ Pada penelitian ini, Peneliti ingin memahami dan mendiskripsikan sejauh mana penerapan managemen risiko kredit pada pembiayaan syariah di Koperasi as Sakinah Sidoarjo serta memahami dan mendiskripsikan skema penyelesaian risiko kredit yang terjadi.

BAB II Ruang Lingkup Managemen Risiko Pasal 3

${ }^{4}$ Sumar'in Asmawi, Juliansyah, "Strategi Manajemen Risiko kredit Murabahah Studi Kasus Di BTN Syariah Yogyakarta”, Asy Sya'iyyah, vol. 1 No 1, (Juni, 2016)

${ }^{5}$ Rifangga C.T Tengor, Sri Murni, dan Silcycjeova Moniharapon, "Penerapan Manajemen Risiko Untuk Meminimalisir Risiko kredit Macet Pada PT. Bank Sulutgo", EMBA Vol. 3 No. 4 (Desember, 2015), 345356

${ }^{6}$ Nur Hasanah, Novi Puspitasari, Lilik Farida, "Risiko Akad Murabahah Serta Pengelolaan Risiko Akad Murabahah Pada BMT-UGT Sidogiri Cabang Wongsorejo, Kabupaten Banyuwangi”, ejurnal Ekonomi Bisnis dan Akuntansi, volume 2 (1), (2015), 1-5 
Penerapan manajemen risiko kredit pada pembiayaan syariah adalah suatu cara/proses menerapkan ${ }^{7}$ serangkaian metodologi dan prosedur yang digunakan untuk mengidentifikasi, mengukur, memantau, dan mengendalikan risiko yang timbul dari kegiatan usaha ${ }^{8}$ kredit akibat kegagalan nasabah atau pihak lain dalam memenuhi kewajiban kepada lembaga keuangan syariah sesuai dengan perjanjian yang disepakati ${ }^{9}$ berupa penyaluran pembiayaan yang dilakukan berdasarkan prinsip syariah. Prinsip syariah adalah ketentuan hukum islam berdasarkan fatwa dan/atau pernyataan kesesuaian syariah dari Dewan Syariah Nasional Majelis Ulama Indonesia. ${ }^{10}$ Dalam penelitian ini pembiayaan syariah dibatasi hanya pada pembiayaan murabahah dan ijarah yang terjadi di Koperasi as Sakinah Sidoarjo. ${ }^{11}$

Metode penelitian yang digunakan dalam penelitian ini adalah metode penelitian kualitatif menggunakan pendekatan studi kasus (case study) menggunakan sumber data primer melalui teknik wawancara

${ }^{7}$ https://kbbi.web.id/terap-2

${ }^{8}$ PBI No 13/23/PBI/2011 tentang Penerapan Manajemen Risiko Bagi Bank Umum Syariah dan Unit Usaha Syariah BAB I Ketentuan Umum Pasal 1

9 Tariqatul Khan dan Habib Ahmed, terj. Ikhwan Abidin Basri, Managemen Risiko Lembaga Keuangan Syariah, (Jakarta: Bumi Aksara, cet. 1, 2008), 12

${ }^{10}$ POJK Nomor 31/POJK.05/2014 tentang Penyelenggaraan Usaha Pembiayaan Syariah

Bab I Ketentuan Umum Pasal 1 ayat 5-6

${ }^{11}$ Zubaidah, Wawancara, Sidoarjo, 9 Januari 2018 dan analisis data sekunder berupa data dan arsip koperasi serta regulasi pemerintah.

Analisis data dilakukan sebelum, selama dan setelah selesai di lapangan, namun porsi terbesar pada saat di lapangan bersamaan dengan pengumpulan data. ${ }^{12}$ Analisis data berupa proses pelacakan dan pengaturan secara sistematis hingga penyajian temuan dengan melibatkan pengerjaan pengorganisasian, pemecahan dan sintesis data serta pencarian pola-pola, pengungkapan hal-hal penting dan penentuan hal-hal yang dilaporkan. ${ }^{13}$

Peneliti menggunakan tiga tahap sebagaimana teori Miles \& Huberman, yaitu mereduksi data, yakni penajaman, penggolongan, dan pengorganisiran data hingga dapat ditarik kesimpulan dan didiversifikasi. ${ }^{14}$ Display $\quad$ data.${ }^{15}$ merupakan sekumpulan informasi tersusun yang memberi memungkinkan adanya penarikan kesimpulan dan pengambilan tindakan. Dengan melihat penyajian tersebut, akan dapat memahami apa yang sedang terjadi dan yang harus dilakukan berdasarkan atas pemahaman ynag didapat dari penyajian-penyajian tersebut.

Untuk langkah ketiga, yakni mengambil kesimpulan dan verifikasi, menurut Miles dan Huberman (2007: 19), Peneliti mulai mencatat

\footnotetext{
${ }^{12}$ Abdullah, Saebani, Metode Penelitian..., 221

${ }^{13} \mathrm{Ibid}, 65$

${ }^{14}$ Prastowo, Metode Penelitian ...,243

${ }^{15}$ Ibid, 245
} 
keteraturan, pola-pola, penjelasan, dan alur sebab-akibat. Kesimpulan semakin jelas dengan adanya data yang rinci serta proses saat analisis.

\section{PEMBAHASAN}

Koperasi as Sakinah Aisyiyah Sidoarjo adalah koperasi yang dirintis oleh PD. 'Aisyiyah Sidoarjo sejak tahun 1999. Sejak tahun 2016, Koperasi ini secara perlahan-lahan telah berubah dari sistem konvensional menjadi sistem syariah. Seluruh kebijakan dan prosedur secara bertahap menyesuaikan dengan pola syariah.

Struktur yang ada di koperasi as Sakinah meliputi pengawas dan DPS, Pengurus, dan Pengelola. Selain itu, dikenal pula istilah pendamping. Pendamping adalah anggota koperasi yang ditunjuk oleh koperasi untuk mendampingi kelompok-kelompok kecil anggota koperasi, Pendamping kelompok memiliki tanggung jawab untuk melakukan pembinaan kepada anggota minimal satu bulan sekali, menghadiri rapat yang diadakan oleh koperasi satu bulan sekali dengan agenda pembinaan, melaporkan perkembangan dan permasalahan yang terjadi dalam kelompok serta menyosialisasikan semua kebijakan koperasi. Masing-masing Pendamping memiliki jumlah kelompok dampingan yang berbeda

Hingga saat ini anggota koperasi as Sakinah Sidoarjo berjumlah 958 orang yang tersebar di seluruh kabupaten Sidoarjo danterhimpun dalam kelompok dengan jumlah anggota antara 5 sampai 10 orang. Pengelompokan bisa karena lingkungan tempat tinggal atau tempat kerja. Setiap kelompok memiliki seorang Ketua, dapat pula ditambahkan sekretaris dan bendahara. Hingga saat ini koperasi as Sakinah membina 57 kelompok. Selain untuk memudahkan pembinaan, fungsi kelompok adalah menentukan diterima atau tidaknya seorang calon anggota serta memberi rekomendasi terhadap pengajuan pembiayaan oleh anggota.

$$
\text { Manfaat yang diperoleh }
$$
anggota koperasi selain dapat mengajukan pembiayaan dan diikutsertakan dalam pameran adalah berbelanja di koperasi as Sakinah dengan pembayaran tunda satu bulan dan gratis biaya pengiriman. Jika ada yang menunggak dalam pembayaran, maka akan berpengaruh pada pengajuan permohonan pembiayaannya serta tunggakan tersebut dianggap sebagai pembiayaan dengan akad tertentu.

Pembiayaan di koperasi as Sakinah dibagi menjadi empat, yakni pembiayaan regular, khusus, emergency, dan hari raya. Pembiayaan regular yaitu pembiayaan diberikan pada anggota dengan jangka waktu yang sudah ditentukan, maksimal 12 bulan. Pembiayaan regular dilakukan dengan sistem tanggung renteng menggunakan akad ijarah. Namun jika ada yang ingin melakukan pembiayaan dengan akad yang lain juga diperbolehkan. Pembiayaan reguler diberikan tanpa jaminan dengan plafon pembiayaan yang ditanggung sebesar $50 \%$ dari dana simpanan yang dimiliki nasabah di Koperasi. Pembiayaan emergency diberikan untuk pengerjaan tender atau kebutuhan jangka pendek 
lainnya maksimal 3 bulan menggunakan akad musyarakah atau mudharabah. Jika lebih dari 3 bulan, maka masuk dalam kategori pembiayaan khusus. Sedang pembiayaan hari raya diberikan untuk kebutuhan merayakan lebaran. Plafon pembiayaan regular yang dapat direalisasikan berkisar antara Rp. 500.000,00 - Rp. 15.000.000,00 tergantung dari dana simpanan yang dimiliki calon nasabah. Realisasi pembiayaan bisa diberikan pada anggota minimal setelah 3 (tiga) bulan menjadi anggota.

Setiap anggota koperasi yang akan melakukan pembiayaan harus memberitahukan kepada ketua kelompok dan mendapat persetujuan minimal $75 \%$ anggota kelompok dan Pendamping. Hal ini dilakukan karena sistem tanggung renteng mengharuskan seluruh kelompok menanggung risiko jika terjadi masalah angsuran pembiayaan dari salah satu anggota kelompok. Pembiayaan yang diajukan oleh anggota dapat direalisasikan jika dalam satu kelompok tidak ada anggota yang bermasalah dalam menyelesaikan angsuran pembiayaannya.

Bendahara kelompok membawa pengajuan beserta seluruh perlengkapannya ke kasir. Oleh kasir diserahkan ke koordinator/kabag analisa untuk dianalisis. Jika pembiayaan dinyatakan bisa direalisasi, maka permohonan diteruskan ke bendahara pengurus untuk dimintakan persetujuan bagi pembiayaan di bawah 15 juta. Dari bendahara pengurus permohonan diberikan ke bagian akad kemudian dikembalikan lagi ke koordinator untuk diberikan ke kasir. Saat pencairan dana atau barang diambil langsung oleh anggota. Sedang untuk pembiayaan di atas 15 juta maka setelah dari bendahara form diserahkan pada Ketua (Pengurus) untuk mendapat persetujuan.

Untuk pembiayaan murabahah setelah permohonan disetujui maka koperasi bersama nasabah membeli barang yang dimaksudkan, kemudian nasabah menghadap bagian akad untuk menandatangani akad untuk kemudian diserahkan ke kasir. Tidak ada form khusus yang disediakan oleh koperasi untuk mengantisipasi nasabah membatalkan pembelian barang. Berkas pembiayaan yang masuk diserahkan ke bagian akad untuk diarsip.Untuk pembiayaan khusus cukup persetujuan Ketua kelompok. Prosedur pengajuan juga berbeda. Nasabah langsung menghadap ke kabag USP untuk dianalisa kemudian ke bendahara dilanjutkan ke Ketua. Setelah itu ke bagian akad.

Setiap melakukan realisasi pembiayaan regular nasabah dikenai dana risiko sebesar $0,25 \%$ dan biaya administrasi sebesar $1 \%$ dari total pembiayaan yang diterima yang dibayarkan sekali saat pembiayaan awal dan dibayarkan tunai, tidak mengambil atau memotong dari dana realisasi. Bagi hasil ijarah ditetapkan sebesar $1,5 \%$ per bulan sedang margin sebesar $25 \%$ dari harga jual barang. Kebijakan keuangan di atas disepakati dalam RK (Rapat kerja).

Pembiayaan murabahah baik untuk kebutuhan produksi maupun 
konsumsi dilakukan dengan sistem murabahah tanpa wakalah, artinya pihak Koperasi bersama dengan nasabah membeli barang yang dimaksudkan. Murabahah dengan wakalah bisa dilakukan dengan syarat bukti pembelian harus segera diserahkan. Hal ini dilakukan jika memang tidak dimungkinkan Pelaksana melakukan pembelian secara langsung. Harga yang diberikan pada nasabah adalah harga sesuai pembelian. Potongan atau discount yang diberikan oleh supplier tidak dihitung sebagai pemasukan bagi koperasi. Discount yang diberikan oleh supplier diberitahukan kepada nasabah sehingga perhitungan bagi hasil didasarkan pada harga riil dari supplier.

Jaminan tidak dipersyaratkan untuk pembiayaan regular, kecuali jika di atas Rp. 15.000.000 atau melebihi plafon. Sedangkan untuk pembiayaan khusus atau emergency diperlukan jaminan. Jaminan bisa berupa SPK (Surat Perjanjian Kerjasama) kontrak kerja nasabah, surat kendaraan bermotor, surat tanah, ataupun personal guarantee. Nilai jaminan adalah sebesar $75 \%$ dari besar pembiayaan. Jika jaminan bukan atas nama sendiri maka harus disertai surat kuasa. Jaminan disimpan tanpa menggunakan akad tertentu. Jaminan tersebut juga tidak dilakukan penyelidikan secara fisik. Koperasi pernah melakukan upaya preventif dengan membuat surat perjanjian di hadapan notaris, namun biaya yang cukup besar memberatkan nasabah pembiayaan. Jaminan dalam bentuk personal guarantee diberikan manakala nasabah tersebut benarbenar dikenal memiliki karakter yang amanah dan memiliki usaha yang jelas. Meski demikian, personal guarantee tidak banyak dilakukan karena berisiko tinggi.

Jika nasabah ingin melunasi pembiayaan lebih cepat dari waktu yang ditentukan, maka nasabah tetap membayar sejumlah penghitungan awal, kecuali untuk murabahah, ada potongan dengan perhitungan tersendiri. Potongan tersebut tidak diperjanjikan di awal namun disampaikan saat terjadi pelunasan lebih cepat.

Pembiayaan bermasalah hanya berkisar $1 \%$ dari seluruh pembiayaan yang ada di koperasi ini. Sedangkan untuk pembiayaan murabahah tidak pernah bermasalah. Hal ini terjadi karena sistem tanggung renteng yang diterapkan oleh koperasi mengharuskan anggota kelompok turut bertanggung jawab menyelesaikan pembiayaan bermasalah dalam kelompoknya. Penyelesaian itu dilakukan dengan cara memberikan dana talangan yang diperoleh melalui patungan antar anggota atau diambil dari tabungan kelompok. Tabungan kelompok bisa berupa tabungan dari anggota kelompok, bisa dari kewajiban menyerahkan sebagian uang pada saat pencairan pembiayaan, atau infaq anggota yang memasarkan produknya saat pertemuan kelompok. Fungsi lain dari tabungan tersebut adalah bisa dimanfaatkan sebagai pembiayaan oleh sesama anggota kelompok tanpa dikenai jasa atau bagi hasil (qardh). Kebijakan tentang tabungan kelompok 
adalah inisiatif anggota kelompok, bukan instruksi dari koperasi.

Jika ada anggota yang ternyata tidak bisa menyelesaikan kewajibannya dalam jangka waktu yang cukup lama, dan anggota kelompok tidak mampu lagi menyelesaikan masalah tersebut, maka penyelesaiannya dilimpahklan ke koperasi. Penyelesaian pembiayaan bermasalah dilakukan dengan menggunakan akad baru dengan jenis akad yang sama. Biasanya dilakukan dengan rescheduling, yakni penambahan waktu untuk menyelesaikan angsurannya. Penyelesaian pembiayaan bermasalah pernah pula dilakukan dengan cara restructuring menggunakan akad qardh. Jika dengan cara di atas ternyata nasabah pembiayaan masih mengalami kesulitan atau mangkir, maka diadakan penghapusan pembiayaan oleh koperasi. Penghapusan bisa dilakukan bagi pembiayaan yang sudah macet selama lima tahun. Setiap tahun, meski tidak banyak, koperasi melakukan penghapusan. Sebelum lima tahun masih diupayakan untuk penyelesaiannya dengan berbagai cara.

Dari data di atas terlihat bahwa koperasi as Sakinah memiliki mekanisme terkait manajemen risiko sejak awal keanggotaan hingga cara penyelesaian masalahnya meskipun tidak disusun secara khusus mengenai pedoman manajemen risiko pembiayaan.

Dilihat dari sisi pengorganisasian Koperasi as Sakinah Sidoarjo belum memiliki unit khusus yang menangani manajemen risiko.
Salah satu unit pelaksana di lapangan adalah unit analisis yang bertugas menganalisa pembiayaan yang diajukan oleh nasabah, namun tidak menganalisis risiko pembiayaan secara umum yang mungkin terjadi di koperasi tersebut.

Kebijakan dan prosedur pembiayaan di Koperasi as Sakinah telah memadai. Namun kebijakan tersebut belum disusun secara sistematis agar terhindar dari kesalahan prosedur. Adanya kelompok-kelompok kecil yang dibentuk oleh koperasi ini memberi keuntungan yang besar pada koperasi dalam rangka mitigasi risiko. Kredibilitas anggota terseleksi sejak awal masuk hingga saat pengajuan pembiayaan. Kelompok-kelompok tersebut juga mampu membantu koperasi dalam menyosialisasikan kebijakan koperasi, sehingga seluruh anggota memahami dengan baik semua aturan yang ada di koperasi as Sakinah.

Sistem tanggung renteng yang diterapkan oleh koperasi ini berperan efektif pula untuk meminimalisir terjadinya risiko. Dalam hal penyelesaian pembiayaan bermasalah, sistem ini mengacu pada akad kafalah dan hawalah dengan adanya tabungan kelompok. Akad kafalah adalah jaminan yang diberikan oleh penanggung (kafiil) kepada pihak ketiga untuk memenuhi kewajiban pihak kedua atau yang ditanggung (makfuul 'anhu, ashil). ${ }^{16}$ Sedangkan hawalah adalah akad pengalihan utang

\footnotetext{
${ }^{16}$ Fatwa Dewan Syari'ah Nasional Nomor 11/DSN-MUI/VI/2000 Tentang Kafalah
} 
dari satu pihak yang berutang kepada pihak lain yang wajib menanggung (membayar)-nya. ${ }^{17}$

Akad pembiayaan yang ada di koperasi ini meliputi akad ijarah, murabahah, mudharabah, dan musyarakah. Namun semua akad tersebut belum dikembangkan dalam bentuk yang lebih spesifik lagi seperti akad ijarah yang dikembangkan menjadi IMBT, murabahah yang dikembangkan menjadi MMT dan pengembangan akad-akad lainnya. Sedang untuk penerapan akad ijarah lebih menekankan pada wakalah bil Ujrah, yakni pemberian kuasa dari koperasi kepada nasabah untuk mengelola dana dengan imbalan pemberian ujrah $(f e e){ }^{18}$

Untuk pembiayaan murabahah pihak koperasi membeli barang tersebut bersama dengan nasabah untuk meminimalisir kerugian akibat nasabah tidak cocok dengan barang tersebut. Namun demikian koperasi perlu membuat perjanjian untuk membeli barang tersebut guna menjaga pembatalan pembelian.

Jaminan yang ditetapkan oleh koperasi sebesar $75 \%$ dari nilai pembiayaan untuk pembiayaan khusus dan emergency, sedang untuk pembiayaan regular sebesar $50 \%$ dari jumlah simpanan pokok. Mengacu pada SOP KJKS bahwa ketentuan yang berlaku adalah nilai jaminan/ agunan sebesar $125 \%$ dan sekurang-

${ }^{17}$ Fatwa Dewan Syari'ah Nasional Nomor 12/DSN-MUI/VI/2000 Tentang Hawalah

18 FATWA DEWAN SYARI'AH NASIONAL Nomor 52/DSN-MUI/III/2006 Tentang Akad Wakalah bil Ujrah pada Asuransi Syari'ah dan Reasuransi Syari'ah kurangnya sebanding dengan nominal pembiayaan yang diajukan oleh calon nasabah. ${ }^{19}$ Belum ada rincian alternatif jaminan, patokan harga masing-masing jaminan dan prosedur eksekusi jaminan jika terjadi pembiayaan bermasalah. Survey lapangan dan crosscheck ke berbagai pihak untuk memastikan keberadaan riil jaminan tersebut juga perlu dilakukan untuk meminimalisir risiko.

Audit internal dilakukan oleh pengawas koperasi secara berkala, sementara audit eksternal baru diusulkan pada saat RK tahun 2016.

Sejauh ini tingkat pembiayaan bermasalah yang terjadi di koperasi as Sakinah sangat rendah. Hal ini terjadi karena seleksi yang dilakukan sangat panjang sejak dari kelompok hingga pengurus, sejak dari penerimaan anggota hingga pengajuan pembiayaan. Namun demikian pengurus perlu untuk membuat standar baku alternatif penyelesaian masalah dan prosedurnya untuk mengantisipasi jika terjadi masalah di kemudian hari.

Pengajuan pembiayaan oleh nasabah dilakukan secara tertulis menggunakan form yang telah disediakan oleh koperasi, demikian juga dengan form akad. Form tersebut kemudian dimasukkan dalam folder menurut jenis akadnya. Khusus tentang dokumentasi dan administrasi jaminan belum ada ketentuan secara baku. Hal ini disebabkan karena pembiayaan yang paling sering dilakukan adalah pembiayaan regular yang tidak membutuhkan jaminan.

\footnotetext{
${ }^{19}$ http://docplayer.info/268325, ...., 113
} 
Mekanisme dan standar keputusan pembiayaan regular telah dimiliki oleh koperasi ini meskipun belum disusun secara sistematis, sedang untuk pembiayaan khusus dan emergency tergantung dari hasil kesepakatan pengurus berdasar masukan dari pengelola. Hal demikian suatu saat akan menimbulkan masalah karena tidak ada standarisasi dan mekanisme yang baku.

Tidak banyak alternatif yang ditawarkan oleh koperasi ini terhadap nasabah yang bermasalah. Hal ini karena kecilnya tingkat pembiayaan bermasalah di koperasi ini sehingga belum ada pilihan-pilihan yang disusun oleh pengurus untuk mengantisipasi risiko pembiayaan di koperasi ini.

Dapat disimpulkan bahwa secara umum koperasi as Sakinah sudah menerapkan prinsip manajemen risiko mesti belum disusun secara sistematis, baik dalam struktur organisasi, prosedur kebijakan maupun analisis.Skema penyelesaian risiko yang pernah terjadi pada pembiayaan syariah di Koperasi as Sakinah Sidoarjo adalah dengan rescheduling dan penghapusbukuan apabila upaya maksimal yang dilakukan tidak membuahkan hasil.

\section{KESIMPULAN}

Koperasi as Sakinah Sidoarjo adalah koperasi yang cukup berhasil dalam mengelola usahanya, terutama unit simpan pinjam. Mekanisme tanggung renteng adalah kunci keberhasilan koperasi ini dari beberapa risiko. Namun demikian perlu ada satu unit yang khusus mengelola manajemen risiko mengingat jumlah aset dan anggota yang cukup banyak dengan sirkulasi keuangan yang cukup besar pula.Kebijakan khususnya tentang pembiayaan hendaknya disusun secara sistematis menjadi sebuah pedoman yang bisa dievaluasi setiap saat untuk menghindari risikorisiko yang mungkin terjadi. Koperasi juga perlu memperbanyak jenis-jenis akad agar penyaluran pembiayaan lebih fleksibel sesuai kebutuhan serta memperbanyak jenis mitigasi risiko dan menyusun prosedur penangannnya.

\section{DAFTAR PUSTAKA}

Nofinawati, Perkembangan Perbankan Syariah Di Indonesia,JURIS Volume 14, Nomor 2 (JuliDesember 2015), 176

Imam Wahyudi, Miranti Kartika Dewi, Muhammad Budi Prasetyo, Niken Iwani Surya Putri, Banu Muhammad Haidir, Manajemen Risiko Bank Islam, (Jakarta: Salemba Empat, 2013), 91

Peraturan OJK Nomor 65/POJK.03/2017 tentang Penerapan Manajemen Risiko Bagi Bank Umum Syariah Dan Unit Usaha Syariah BAB II Ruang Lingkup Managemen Risiko Pasal 3

Sumar'in Asmawi, Juliansyah, "Strategi Manajemen Risiko kredit Murabahah Studi Kasus Di BTN Syariah Yogyakarta", Asy Sya'iyyah, vol. 1 No 1, (Juni, 2016)

Rifangga C.T Tengor, Sri Murni, dan Silcycjeova Moniharapon, 
"Penerapan Manajemen Risiko Untuk Meminimalisir Risiko kredit Macet Pada PT. Bank Sulutgo", EMBA Vol. 3 No. 4 (Desember, 2015), 345-356

Nur Hasanah, Novi Puspitasari, Lilik Farida, "Risiko Akad Murabahah Serta Pengelolaan Risiko Akad Murabahah Pada BMT-UGT Sidogiri Cabang Wongsorejo, Kabupaten Banyuwangi", ejurnal Ekonomi Bisnis dan Akuntansi, volume 2 (1), (2015), 1-5

https://kbbi.web.id/terap-2

PBI No 13/23/PBI/2011 tentang Penerapan Manajemen Risiko Bagi Bank Umum Syariah dan Unit Usaha Syariah BAB I Ketentuan Umum Pasal 1

Tariqatul Khan dan Habib Ahmed, terj. Ikhwan Abidin Basri, Managemen Risiko Lembaga Keuangan Syariah, (Jakarta: Bumi Aksara, cet. 1, 2008)

POJK Nomor 31/POJK.05/2014 tentang Penyelenggaraan Usaha Pembiayaan Syariah perasi
Bab I Ketentuan Umum Pasal 1 ayat 5-6

Zubaidah, Wawancara, Sidoarjo, 9 Januari 2018

Abdullah, Saebani, Metode Penelitian..., 221

Andi Prastowo,Metode Penelitian Kualitatif Dalam Perspektif Rancangan Penelitian, cet. 3 (Yogyakarta: Ar Ruzz Media, 2014)

Fatwa Dewan Syari'ah Nasional Nomor 11/DSN-MUI/VI/2000 Tentang Kafalah

Fatwa Dewan Syari'ah Nasional Nomor 12/DSN-MUI/VI/2000 Tentang Hawalah

Fatwa Dewan Syari'ah Nasional Nomor 52/DSN-MUI/III/2006 Tentang Akad Wakalah bil Ujrah pada Asuransi Syari'ah dan Reasuransi Syari'ah

http://docplayer.info/268325-Standaroperasional-prosedur-koperasi-jasakeuangan-syariah-dan-unit-jasakeuangan-syariah-koperasi.html, Standar Operasional Prosedur KJKS dan UJKS Ko 